\title{
SINTESIS DAN KARAKTERISASI MATERIAL FOTOKATALIS Na2Ti6O13 MENGGUNAKAN METODE HIDROTERMAL
}

\author{
Cukri Rahma ${ }^{1}$ \\ ${ }^{1)}$ Jurusan Teknik Industri, Fakultas Teknik, Universitas Teuku Umar \\ Email: cukri.rahma@gmail.com
}

\begin{abstract}
The aim of the reasearh was to get photocatalytic material of $\mathrm{Na}_{2} \mathrm{Ti}_{6} \mathrm{O}_{13}$ with hydrotermal method. Hydrotermal method is environmentally frendly way. This matter becaused hydrothermal method is using materials that are safe for life. Sodium hexa titanate is a semiconductor matterial that is widely used in various fields, such as is used as a photocatalyst material. From the characterization results, $\mathrm{Na}_{2} \mathrm{Ti}_{6} \mathrm{O}_{13}$ with size of $48.44 \mathrm{~nm}$, and energy gap of $3.40 \mathrm{eV}$ has been prepared. $\mathrm{Na}_{2} \mathrm{Ti}_{6} \mathrm{O}_{13}$ has a monoclinic crystal system with lattice parameters of $a=15.210 \AA, b=3.744 \AA, c=9.165 \AA$, and $\beta=$ $99.050^{\circ}$. Photocatalyst activity was tested under UV light irradiation for 3 hours. Degradation of methylene blue (MB) by $\mathrm{Na}_{2} \mathrm{Ti}_{6} \mathrm{O}_{13}$ is found to be at $51 \%$.
\end{abstract}

Keywords: Photocatalyst, $\mathrm{Na}_{2} \mathrm{Ti}_{6} \mathrm{O}_{13}$, Degradation methylene blue

\section{PENDAHULUAN}

Dari tahun ke tahun jumlah penduduk dunia semakin bertambah. Indonesia merupakan salah satu negara berkembang di dunia yang juga mengalami pertumbuhan jumlah penduduk. Pertumbuhan tersebut menimbulkan dampak terhadap berbagai aspek kehidupan manusia. Salah satu aspek yang cukup berpengaruh adalah peningkatan penggunaan energi, terutama energi bahan bakar. Energi bahan bakar merupakan energi yang dibutuhkan untuk menunjang kehidupan manusia di berbagai sektor, yang meliputi sektor industri, transportasi, rumah tangga dan lain sebagainya.

Kebutuhan energi bahan bakar berubah dari kebutuhan sekunder menjadi kebutuhan primer, Sumber energi bahan bakar yang diperoleh selama ini hanya dari energi fosil seperti minyak bumi, gas alam, dan batu bara. Masalah yang terkait dengan pemanfaatan energi fosil, di antaranya energi fosil tidak dapat diperbaharui dalam waktu yang cepat dan keberadaannya yang semakin menipis. Oleh karena itu, para ilmuan terus meneliti dan berusaha menemukan sumber energi baru untuk mengatasi masalah tersebut dengan energi yang terbarukan.

Ada beberapa cara yang ditawarkan untuk menggantikan energi fosil salah satunya adalah pemanfaatan energi alternatif seperti hidrogen. Bahan bakar hidrogen merupakan energi yang ramah lingkungan. Hasil pembakaran hidrogen tidak menyebabkan polusi. Selain itu, hidrogen juga bersifat portable dan lebih efisien dibandingkan energi lain. Hidrogen memiliki kandungan energi $122 \mathrm{~kJ} / \mathrm{g}, 2,75$ lebih besar daripada energi yang dihasilkan oleh bahan bakar hidrokarbon seperti metana dan etana [1]. Dengan demikian diharapkan hidrogen dapat menggantikan keberadaan energi fosil.

Hidrogen adalah unsur yang paling melimpah dengan persentase kira-kira $75 \%$ dari total massa unsur di alam semesta. Hidrogen merupakan molekul yang sangat reaktif. Keberadaan hidrogen di alam lebih banyak membentuk senyawa dengan unsur lain. 
Seperti metana $\left(\mathrm{CH}_{4}\right)$, air $\left(\mathrm{H}_{2} \mathrm{O}\right)$ dan sebagainya. Oleh karena itu, untuk menggunakan gas hidrogen harus dipisahkan terlebih dahulu dari senyawanya.

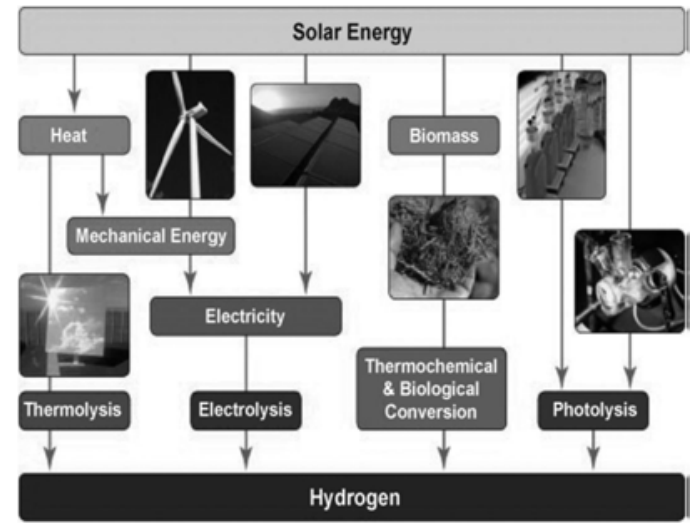

Gambar 1. Metode produksi hidrogen [1].

Hidrogen secara industri dihasilkan melalui beberapa metode, di antaranya steam reforming dan gasifikasi biomassa. Kedua metode tersebut dapat menghasilkan hidrogen dalam jumlah yang banyak. Namun, melalui pembakaran tersebut juga menghasilkan limbah seperti karbon dioksida $\left(\mathrm{CO}_{2}\right)$ dan karbon monoksida $(\mathrm{CO})$ yang sangat berbahaya bagi makhluk hidup. Metode lain yang digunakan untuk menghasilkan hidrogen adalah melalui reaksi elektrolisis air. Metode ini memang tanpa emisi. Akan tetapi, dari segi konsumsi energi cara ini membutuhkan energi listrik yang cukup besar. Oleh sebab itu, metode-metode tersebut kurang efisien untuk digunakan. Sehingga perlu mencari metode lain yang tidak menghasilkan emisi dan harganya juga terjangkau. Metode yang disarankan memenuhi kriteria tersebut adalah melalui reaksi fotokatalitik.

Reaksi fotokatalitik adalah reaksi yang terjadi ketika diberikan energi cahaya. Reaksi fotokatalitik melibatkan katalis yang dinamakan fotokatalis. Reaksi fotokatalitik akan terjadi apabila fotokatalis menyerap energi foton lebih besar atau sama dengan lebar celah pita energi dari fotokatalis tersebut. Fotokatalis yang biasa digunakan pada dasarnya adalah semikonduktor. Semikonduktor mempunyai struktur elektronik yang berbeda dari bahan lain, yaitu adanya pita konduksi (bagian teratas dari semikonduktor yang tidak terisi elektron) dan pita valensi (bagian terbawah dari semikonduktor yang terisi elektron). Jarak yang memisahkan antara pita konduksi dengan pita valensi disebut dengan lebar celah pita energi (band gap).

Reaksi fotokatalitik digunakan karena memiliki beberapa kelebihan, di antaranya menggunakan air sebagai bahan dasar dan sinar matahari sebagai sumber energi. Di mana air dan cahaya matahari terdapat berlimpah di alam. Selain itu metode ini juga zero emission karena hanya menghasilkan hidrogen dan oksigen. Akan tetapi penggunaan reaksi fotokatalitik juga masih mempunyai kendala.

Kendala penggunaan reaksi fotokatalitik adalah efisiensi reaksi fotokatalitik yang masih rendah. Vithal menyatakan bahwa efisiensi reaksi fotokatalitik dipengaruhi oleh beberapa faktor seperti ukuran kristal fotokatalis, celah pita energi fotokatalis, dan terjadi reaksi rekombinasi elektron dan hole [2].

Natrium heksa titanat $\left(\mathrm{Na}_{2} \mathrm{Ti}_{6} \mathrm{O}_{13}\right)$ merupakan material yang sudah dikenal dan digunakan dalam berbagai aplikasi seperti sebagai material fotokatalis, sebagai ion baterai litium, sebagai gas sensor, sebagai prekursor untuk mendapatkan material dielektrik, ferroelektrik, dll [3]. Selain itu, $\mathrm{Na}_{2} \mathrm{Ti}_{6} \mathrm{O}_{13}$ sebagai metrial fotokatalis juga memperlihatkan aktivitas fotokatalitik yang baik serta kestabilan termal yang bagus [4]. 
Fotokatalis merupakan gabungan dua kata yaitu foto dan katalis, sehingga dapat diartikan sebagai suatu proses kombinasi reaksi fotokimia yang memerlukan unsur cahaya dan katalis untuk mempercepat terjadinya transformasi kimia. Transformasi tersebut terjadi pada permukaan katalis. Katalis yang digunakan disebut sebagai fotokatalis. Salah satu contoh material fotokatalis yang sering digunakan adalah semikonduktor oksida [5].

Fenomena fotokatalisis pertama kali dilakukan oleh Renz pada tahun 1921. Dalam penelitiannya dia melaporkan fenomena yang terjadi pada permukaan semikonduktor oksida [4]. Akan tetapi, penelitian tersebut kurang diminati pada saat itu. Isu krisis energi pada masa-masa selanjutnya membuat fotokatalis menjadi semakin popular karena dapat menghasilkan hidrogen yang ramah lingkungan. Pada tahun 1972, Fujishima dan Honda memplubikasikan fenomena fotokatalis di mana terjadi pemecahan $\mathrm{H}_{2} \mathrm{O}$ menjadi hidrogen dan oksigen dengan memberikan sinar UV yang memiliki enargi rendah [6]. Aplikasi teknologi untuk fenomena ini menjadi lahan penelitian bagi peneliti dunia yang terus berkembang.

Semikonduktor adalah sebuah bahan dengan konduktivitas listrik yang berada di antara isolator dan konduktor. Semikonduktor merupakan material yang dapat digunakan sebagai material fotokatalis. Semikonduktor natrium heksa titanat $\left(\mathrm{Na}_{2} \mathrm{Ti}_{6} \mathrm{O}_{13}\right)$, termasuk ke dalam kelompok alkali titanat dengan rumus umum $\mathrm{A}_{2} \mathrm{O}_{n} \mathrm{nTiO}_{2}(3 \leq \mathrm{n} \leq 8, \mathrm{~A}=\mathrm{Li}, \mathrm{Na}$, K). kristal $\mathrm{Na}_{2} \mathrm{Ti}_{6} \mathrm{O}_{13}$ tersusun dari ion natrium $\left(\mathrm{Na}^{+}\right)$yang diikat oleh $\mathrm{TiO}_{6}$ oktahedral dalam unit lapisan-lapisan $\mathrm{Ti}_{6} \mathrm{O}_{13}{ }^{2-}$ membentuk rectangular tunnel $[2,10,22]$.

$\mathrm{Na}_{2} \mathrm{Ti}_{6} \mathrm{O}_{13}$ memiliki nilai lebar celah pita energi sebesar 3,53 eV $[9,13] . \mathrm{Na}_{2} \mathrm{Ti}_{6} \mathrm{O}_{13}$ mempunyai sistem kristal monoklinik, grup ruang $C 2 / m$ dan parameter cell ; $\mathrm{a}=15,1032$ $\AA, \mathrm{b}=3,74373 \AA, \mathrm{c}=9,1713 \AA$, dan $\beta=99,056^{\circ}$ [23]. Struktur $\mathrm{Na}_{2} \mathrm{Ti}_{6} \mathrm{O}_{13}$ dapat dilihat pada Gambar 2.

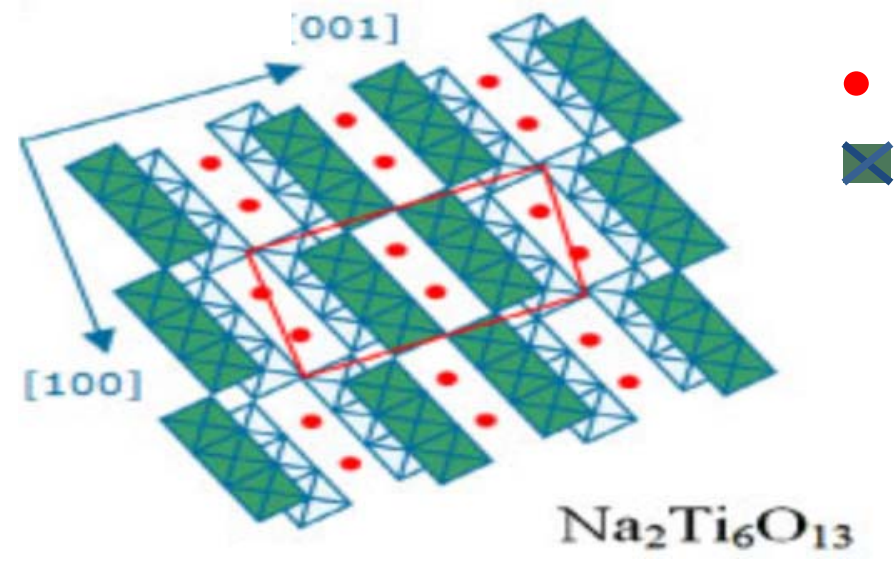

Gambar 2. Skema representasi struktur kristal $\mathrm{Na}_{2} \mathrm{Ti}_{6} \mathrm{O}_{13}$ [22].

$\mathrm{Na}_{2} \mathrm{Ti}_{6} \mathrm{O}_{13}$ merupakan material yang sudah dikenal sebagai material fotokatalis karena mempunyai aktivitas fotokatalis dan sifat transport elektrik yang sangat baik sehingga dapat digunakan untuk mendegradasi zat beracun [10]. $\mathrm{Na}_{2} \mathrm{Ti}_{6} \mathrm{O}_{13}$ dengan struktur nano tunnel dapat diperoleh dari perlakuan pada suhu tinggi.

Reaksi fotokatalis dengan menggunakan $\mathrm{Na}_{2} \mathrm{Ti}_{6} \mathrm{O}_{13}$ sudah banyak dikembangkan dalam berbagai sektor, seperti teknologi produksi hidrogen dari air $\left(\mathrm{H}_{2} \mathrm{O}\right)$ [13]. Dalam reaksi ini, bahan baku yang diperlukan hanya air dan katalis yang diaktivasi oleh cahaya matahari. Dalam prosesnya, teknologi ini memberikan untung yang besar karena menggunakan air dan sinar matahari yang terdapat melimpah di bumi.

Aplikasi lain dari teknologi yang menggunakan material fotokatalis $\mathrm{Na}_{2} \mathrm{Ti}_{6} \mathrm{O}_{13}$ adalah dapat digunakan untuk mendegradasi limbah organik berbahaya, yang dihasilkan 
oleh kegiatan manusia, baik industri maupun rumah tangga. $\mathrm{Na}_{2} \mathrm{Ti}_{6} \mathrm{O}_{13}$ juga digunakan sebagai prekursor untuk mendapatkan senyawa ferroelectric, piezzoelectric, dielectric. Sebagai material anoda pada ion baterai litium [14].

Metode hidrotermal merupakan metode yang sudah digunakan untuk sintesis material anorganik beberapa tahun yang lalu. Hidrotermal merupakan suatu metode sintesis material yang menggunakan reaksi satu tahap dalam media air pada temperatur rendah dan tekanan tinggi $(\mathrm{P}>100 \mathrm{kPa})$. Metode hidrotermal memiliki beberapa keuntungan, di antaranya mengurangi waktu reaksi, menghasilkan produk kristal yang homogen pada temperatur rendah (di bawah $150{ }^{\circ} \mathrm{C}$ ) dan juga dapat mengurangi terjadinya penggumpalan di antara partikel $[13,18,20]$. Rosiyah et al, telah melakukan sintestis kalium heksa titanat $\left(\mathrm{K}_{2} \mathrm{Ti}_{6} \mathrm{O}_{13}\right)$ menggunakan metode hidrotermal, mendapatkan $\mathrm{K}_{2} \mathrm{Ti}_{6} \mathrm{O}_{13}$ dengan ukuran kristal yang besar pada suhu superkritik [19].

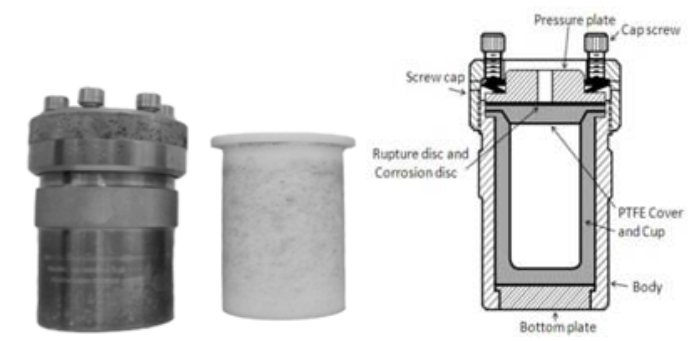

Gambar 3. Foto autoclave yang digunakan pada metode hidrotermal.

Beberapa metode yang sudah pernah dilakukan untuk melakukan sintesis $\mathrm{Na}_{2} \mathrm{Ti}_{6} \mathrm{O}_{13}$. Secara konvensional, Sten Andersson telah melalukan sintesis $\mathrm{Na}_{2} \mathrm{Ti}_{6} \mathrm{O}_{13}$ melalui reaksi padatan $\mathrm{Na}_{2} \mathrm{CO}_{3}$ dan $\mathrm{TiO}_{2}$. Kemudian dikalsinasi pada temperatur tinggi yaitu temperatur $1100{ }^{\circ} \mathrm{C}$. Perbandingan campuran $\mathrm{Na}_{2} \mathrm{CO}_{3}$ dan $\mathrm{TiO}_{2}$ dengan rasio molar 1:6 menghasilkan $\mathrm{Na}_{2} \mathrm{Ti}_{6} \mathrm{O}_{13}$ tidak berwarna. $\mathrm{Na}_{2} \mathrm{Ti}_{6} \mathrm{O}_{13}$ yang dihasilkan menunjukkan aktivitas fotokatalis yang baik untuk mendegradsi rhodamin B di bawah radiasi sinar UV [12].

Metode hidrotermal yang digunakan dalam penelitian ini merujuk kepada penelitian Zarrate. Zarrate telah melakukan sisntesis $\mathrm{Na}_{2} \mathrm{Ti}_{6} \mathrm{O}_{13}$ melalui metode hidrotermal mempunyai struktur tube-like menunjukkan fasa yang stabil pada suhu tinggi aktivitas fotokatalis yang tinggi [21].

\section{METODE PENELITIAN}

Material awal yang digunakan untuk melakukan sintesis $\mathrm{Na}_{2} \mathrm{Ti}_{6} \mathrm{O}_{13}$ semua berasal dari gudang penyimpanan bahan kimia yang ada di laboratorium MIPA kimia. Masingmasing prekursor ditimbang dengan menggunakan timbangan digital. $\mathrm{NaOH}$ ditimbang sebanyak 10,110 gram, kemudian dilarutkan ke dalam $25 \mathrm{ml}$ aquades untuk membuat larutan $\mathrm{NaOH}$ dengan konsentrasi $10 \mathrm{M}$. Selanjutnya, 0,211 gram $\mathrm{TiO}_{2}$ ditambahkan ke dalam larutan $\mathrm{NaOH}$. Campuran diaduk menggunakan magnet stirre dengan kecepatan $300 \mathrm{rpm}$ selama \pm 2 jam pada suhu ruang [20].

Campuran keruh yang diperoleh, kemudian dipindahkan ke dalam autoclave. Autoclave yang digunakan harus terbuat dari bahan yang tahan terhadap tekanan dan suhu tinggi, seperti baja untuk mempertahankan suhu dan tekanan selama pemanasan. Kemudian dipanaskan dalam oven selama 24 jam pada suhu $150^{\circ} \mathrm{C}$. Setelah pemanasan, endapan putih dipisahkan dan dicuci dengan larutan $\mathrm{HCl} \mathrm{0,01} \mathrm{M}$ dan aquades beberapa 
kali sampai $p H \leq 7$. Endapan yang diperoleh, selanjutnya dikeringkan dalam oven pada suhu $100^{\circ} \mathrm{C}$.

Serbuk putih yang diperoleh kemudian dibuat dalam bentuk pellet. Pellet kemudian dikalsinasi dalam furnace pada suhu $500{ }^{\circ} \mathrm{C}$ selama 24 jam. Kecepatan laju kenaikan suhu pemanasan diatur $10{ }^{\circ} \mathrm{C} /$ menit. Begitu juga suhu pendinginan diatur $5{ }^{\circ} \mathrm{C} /$ menit. Pekerjaan pada tahap hidrotermal dilakukan secara berulang kali. Hal ini dilakukan untuk mendapatkan beberapa sampel, yang selanjutnya dikalsinasi pada suhu yang berbeda-beda yaitu $600{ }^{\circ} \mathrm{C}, 800{ }^{\circ} \mathrm{C}$, dan $1000{ }^{\circ} \mathrm{C}$. Masing-masing $\mathrm{Na}_{2} \mathrm{Ti}_{6} \mathrm{O}_{13}$ yang diperoleh kemudian dilakukan karakterisasi menggunakan analisis powder $x$-ray diffraction (XRD), scanning electron microscopy (SEM) dan diffuse refflectance spectroscopy (DRS).

\section{HASIL DAN PEMBAHASAN}

Pada bagian ini akan dilaporkan hasil sintesis dan karakterisasi dari senyawa hasil sintesis. Sampel dipreparasi melalui metode hidrotermal dari material awalnya. Kemudian, setelah proses hidrotermal diikuti dengan proses kalsinasi selama 24 jam dan selanjutnya menghasilkan material berupa serbuk putih. Sampel yang dihasilkan kemudian dilakukan karakterisasi menggunakan XRD untuk mengetahui struktur dan kristalinitasnya. Selanjutnya data XRD serbuk ini dilakukan refinement untuk mengetahui sistem kristalnya. Metode yang digunakan untuk refinement data XRD adalah metode Le Bail menggunakan program fullProf Suite 2.05. Pengukuran UV reflektan dilakukan untuk menentukan lebar celah pita energi dari sampel. Karakterisasi lain yang dilakukan adalah SEM untuk melihat morfologi dari sampel hasil sintesis.

\subsection{Analisis XRD dan Refinement}

Proses sintesis Sampel $\mathrm{Na}_{2} \mathrm{Ti}_{6} \mathrm{O}_{13}$, diawali dengan melarutkan material awal yaitu 20 gram $\mathrm{NaOH}$ ke dalam $50 \mathrm{ml}$ aquades untuk membuat larutan $\mathrm{NaOH} 10 \mathrm{M}$. Ke dalam larutan $\mathrm{NaOH}$, kemudian ditambahkan 0,21 gram $\mathrm{TiO}_{2}$. $\mathrm{NaOH}$ digunakan sebagai sumber ion logam untuk membentuk kisi kristal $\mathrm{Na}_{2} \mathrm{Ti}_{6} \mathrm{O}_{13}$ yang dikelilingi oleh ion $\mathrm{Ti}_{6} \mathrm{O}_{13}{ }^{2-}$. Wadah tempat reaksi berubah menjadi panas. Hal ini menunjukkan bahwa kalor pelarutan $\mathrm{NaOH}$ bernilai negatif (eksoterm). $\mathrm{TiO}_{2}$ susah larut dalam $\mathrm{NaOH}$, sehingga perlu dipanaskan secara hidrotermal. Campuran selanjutnya dipanaskan dalam oven. Serbuk putih yang diperoleh, kemudian dicuci dan selanjutnya dikalsinasi.

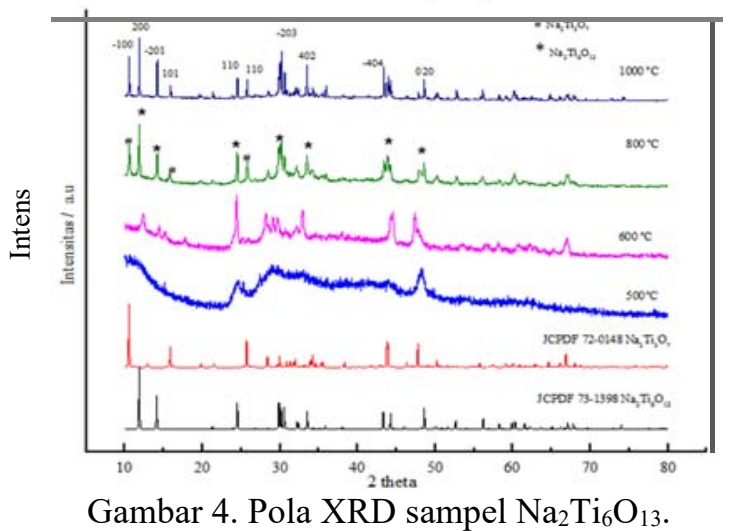


Sampel $\mathrm{Na}_{2} \mathrm{Ti}_{6} \mathrm{O}_{13}$ hasil kalsinasi dengan perbedaan suhu, digerus sampai homogen untuk dilakukan karakterisasi menggunakanv XRD-serbuk. Radiasi sinar-X yang digunakan adalah pada panjang gelombang $\mathrm{Cu}-\mathrm{K} \alpha$. Pengukuran dilakukan pada rentang sudut $2 \theta^{\circ}$ yang digunakan adalah $5^{\circ}$ sampai $80^{\circ}$.

Gambar 4 merupakan kurva hasil XRD untuk masing-masing sampel yang dikalsinasi pada suhu yang berbeda-beda. $\mathrm{Na}_{2} \mathrm{Ti}_{6} \mathrm{O}_{13}$ belum terbentuk pada suhu kalsinasi $500{ }^{\circ} \mathrm{C}$. Akan tetapi $\mathrm{Na}_{2} \mathrm{Ti}_{6} \mathrm{O}_{13}$ mulai terbentuk pada suhu kalsinasi $600{ }^{\circ} \mathrm{C}$.

Pada suhu kalsinasi $800{ }^{\circ} \mathrm{C}$ dan $1000{ }^{\circ} \mathrm{C}, \mathrm{Na}_{2} \mathrm{Ti}_{6} \mathrm{O}_{13}$ sudah jelas pembentukannya. Pembentukan $\mathrm{Na}_{2} \mathrm{Ti}_{6} \mathrm{O}_{13}$ terlihat dari puncak difraksi $\mathrm{Na}_{2} \mathrm{Ti}_{6} \mathrm{O}_{13}$ yang khas yaitu pada $2 \theta=11,8^{\circ}, 14,1^{\circ}$, dan $30,1^{\circ}$ yang merupakan puncak difraksi dengan intensitas tertinggi. Data yang diperoleh sesuai dengan referensi (JCPDS 73-1398). Suhu kalsinasi mempengaruhi sifat kristalin dari $\mathrm{Na}_{2} \mathrm{Ti}_{6} \mathrm{O}_{13}$, di mana semakin tinggi suhu kalsinasi kristalinitas $\mathrm{Na}_{2} \mathrm{Ti}_{6} \mathrm{O}_{13}$ semakin tinggi.

Pada suhu kalsinasi $800{ }^{\circ} \mathrm{C}$ dan $1000{ }^{\circ} \mathrm{C}$ terbentuk fasa pengotor. Hal itu, terlihat dari pola difraksi pada $2 \theta=10,5^{\circ}$ dan $15,8^{\circ}$. Setelah dilakukan intepretasi terhadap pola pengotor tersebut, ditemukan bahwa pengotor tersebut adalah natrium tri titanat $\left(\mathrm{Na}_{2} \mathrm{Ti}_{3} \mathrm{O}_{7}\right)$ (JCPDF 72-0148), merupakan fasa transisi dari $\mathrm{Na}_{2} \mathrm{Ti}_{6} \mathrm{O}_{13}$. Terbentuknya fasa $\mathrm{Na}_{2} \mathrm{Ti}_{3} \mathrm{O}_{7}$ diperkirakan karena suhu hidrotermal yang digunakan masih rendah, sehingga fasa $\mathrm{Na}_{2} \mathrm{Ti}_{3} \mathrm{O}_{7}$ belum berubah ke fasa $\mathrm{Na}_{2} \mathrm{Ti}_{6} \mathrm{O}_{13}$. Hal ini sesuai dengan pernyataan Hongwei, bahwa stretching Ti-O yang melibatkan oksigen terminal pada natrium tri titanat melemah seiring dengan kenaikan suhu. Dan pada natrium hesksa titanat tidak ada stretching oksigen terminal karena strukturnya merupakan tunnel berbeda dengan natrium tri titanat mempunyai struktur berlapis [21]. Data XRD yang diperoleh selanjutnya digunakan untuk menentukan ukuran kristal rata-rata menggunakan persamaan Scherrer.

$$
D=\frac{K \lambda}{\beta \cos \theta}
$$

Dimana, $D$ adalah ukuran kristal, $\mathrm{K}$ adalah konstanta Scherrer $(0,89), \lambda$ adalah panjang gelombang difraksi sinar-X yang digunakan $(\lambda=1,54056 \AA), \beta$ adalah lebar setengah puncak difraksi maksimum (full width at half maximum, FWHM) dihitung dalam satuan radian, dan $\theta$ adalah sudut difraksi yang terbaca oleh mesin XRD. Puncak difraksi yang digunakan untuk menghitung ukuran kristal adalah puncak pada $2 \theta=11,8^{\circ}$ (200).

Hasil perhitungan ukuran kristal disajikan pada Tabel 1. Untuk sampel yang dikalsinasi pada suhu $500{ }^{\circ} \mathrm{C}$ dan $600{ }^{\circ} \mathrm{C}$ tidak dapat dihitung ukurannya, karena sampel tersebut masih belum terbentuk. Persen fraksi volume $\mathrm{Na}_{2} \mathrm{Ti}_{6} \mathrm{O}_{13}$ dibandingkan dengan fasa kedua yaitu $\mathrm{Na}_{2} \mathrm{Ti}_{3} \mathrm{O}_{7}$ ditunjukkan pada Gambar 5 Semakin tinggi suhu kalsinansi, fasa $\mathrm{Na}_{2} \mathrm{Ti}_{3} \mathrm{O}_{7}$ semakin berkurang.

Tabel 1. Hasil perhitungan ukuran rata-rata kristal $\mathrm{Na}_{2} \mathrm{Ti}_{6} \mathrm{O}_{13}$ yang dikalsinasi pada suhu yang berbeda

\begin{tabular}{cccc}
\hline No & $\begin{array}{c}\text { Suhu kalsinasi } \\
\mathrm{Na}_{2} \mathrm{Ti}_{6} \mathrm{O}_{13}\left({ }^{\circ} \mathrm{C}\right)\end{array}$ & FWHM $d_{200}(\mathrm{rad})$ & $\mathrm{D}(\mathrm{nm})$ \\
\hline \hline 1 & 500 & - & - \\
2 & 600 & - & - \\
3 & 800 & 0,00287 & 48,31 \\
4 & 1000 & 0,00123 & 112,72 \\
\hline \hline
\end{tabular}




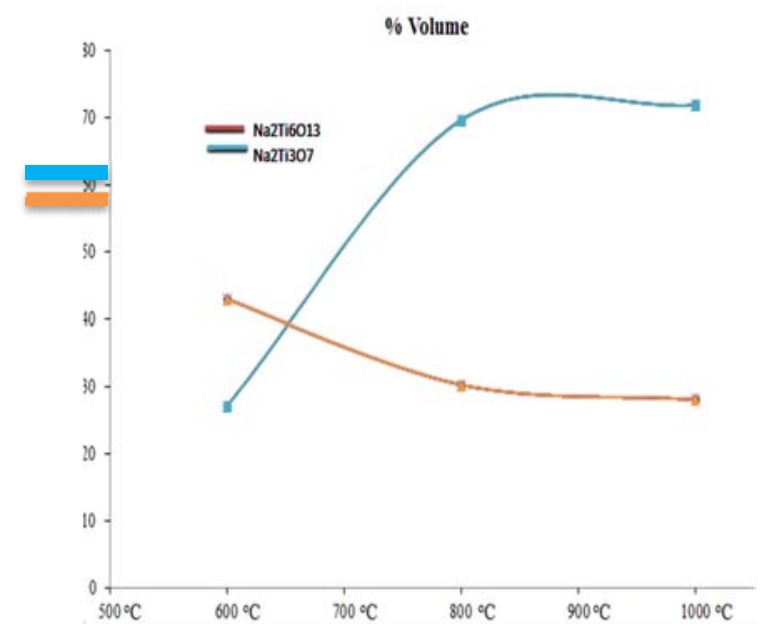

Gambar 5. Perbandingan fraksi volume fasa yang terbentuk.

Gambar hasil refinement untuk masing-masing sampel $\mathrm{Na}_{2} \mathrm{Ti}_{6} \mathrm{O}_{13}$ yang dilakukan menggunakan metode Le Bail ditunjukkan pada gambar 6 dan parameter sel disajikan dalam tabel 2. Sampel yang dikalsinasi pada suhu $500{ }^{\circ} \mathrm{C}$ tidak dilakukan karena masih berupa amorf. Hasil refinement yang diperoleh mirip dengan hasil yang dilakukan oleh Jusn Carlos et al, di mana $\mathrm{Na}_{2} \mathrm{Ti}_{6} \mathrm{O}_{13}$ mempunyai $\mathrm{a}=15,1032 \AA ; \mathrm{b}=3,743 \AA ; \mathrm{c}=9,171$ $\AA$; dan $\beta=99,056^{\circ}[23]$.

Tabel 2. Parameter sel hasil refinement sampel $\mathrm{Na}_{2} \mathrm{Ti}_{6} \mathrm{O}_{13}$ pada berbagai suhu kalsinasi dengan metode Le Bail.

\begin{tabular}{cccc}
\hline $\begin{array}{c}\text { Parameter sel } \\
\mathrm{Na}_{2} \mathrm{Ti}_{6} \mathrm{O}_{13}\end{array}$ & $1000^{\circ} \mathrm{C}$ & $800^{\circ} \mathrm{C}$ & $600{ }^{\circ} \mathrm{C}$ \\
\hline \hline Sistem kristal & monoklinik & monoklinik & monoklinik \\
Grup ruang & $2 / \mathrm{m}$ & $2 / \mathrm{m}$ & $2 / \mathrm{m}$ \\
$\boldsymbol{a}$ & $15,095(\AA)$ & $15,121(\AA)$ & $14,614(\AA)$ \\
$\mathrm{b}$ & $3,744(\AA)$ & $3,747(\AA)$ & $3,624(\AA)$ \\
$\boldsymbol{c}$ & $9,168(\AA)$ & $9,156(\AA)$ & $8,226(\AA)$ \\
$\boldsymbol{\beta}$ & $98,99^{\circ}$ & $99,05^{\circ}$ & $99,12^{\circ}$ \\
$\mathrm{R}_{\mathrm{p}}(\%)$ & 7,94 & 7,94 & 10,0 \\
$\mathrm{R}_{\mathrm{wp}}(\%)$ & 10,2 & 10,3 & 13,5 \\
$\mathrm{Z}$ & 8 & 8 & 8 \\
\hline \hline
\end{tabular}

Dari hasil refinment diperoleh nilai $\mathrm{R}_{\mathrm{p}}$ dan $\mathrm{R}_{\mathrm{wp}}$ yang berada pada rentang yang dapat diterima untuk suatu proses refinement dan puncak-puncak difraksi telah menunjukkan bahwa senyawa yang terbentuk adalah $\mathrm{Na}_{2} \mathrm{Ti}_{6} \mathrm{O}_{13}$. Oksida pengotor berupa $\mathrm{Na}_{2} \mathrm{Ti}_{3} \mathrm{O}_{7}$ untuk sampel yang dikalsinasi pada suhu $800{ }^{\circ} \mathrm{C}$ dan $1000{ }^{\circ} \mathrm{C}$, sedangkan pada suhu kalsinasi $600^{\circ} \mathrm{C}$ masih terdapat $\mathrm{TiO}_{2}$ dan $\mathrm{Na}_{1.7} \mathrm{Ti}_{6} \mathrm{O}_{11}$.

\subsection{Analisis Morfologi}

Morfologi dari sampel hasil sintesis dapat diketahui dengan melakukan analisis SEM. Secara umum morfologi semua sampel dapat dilihat pada Gambar 7 Sampel yang dikalsinasi pada suhu $500{ }^{\circ} \mathrm{C}$ dan $600{ }^{\circ} \mathrm{C}$ terlihat masih amorf. Kristal terbentuk pada suhu kalsinasi yang lebih tinggi yaitu $800^{\circ} \mathrm{C}$ dan $1000{ }^{\circ} \mathrm{C}$ dengan ukuran yang besar. Hal ini mengindikasikan bahwa kristal $\mathrm{Na}_{2} \mathrm{Ti}_{6} \mathrm{O}_{13}$ terbentuk pada suhu kalsinasi yang tinggi. 

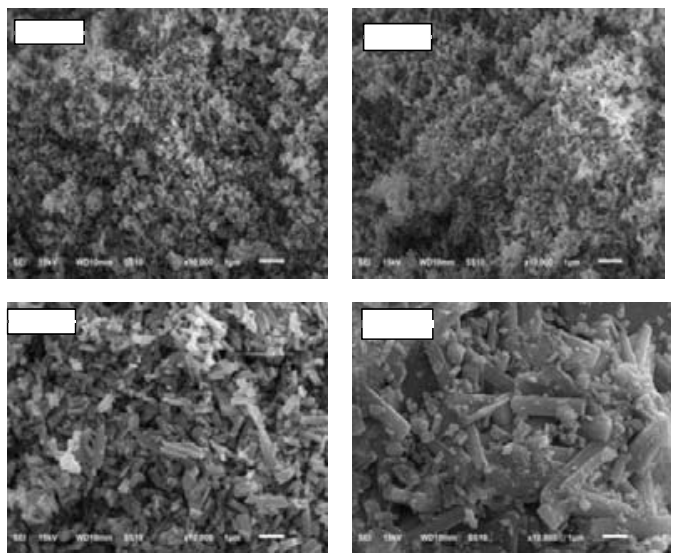

Gambar 7. Foto SEM sampel $\mathrm{Na}_{2} \mathrm{Ti}_{6} \mathrm{O}_{13}$ setelah kalsinasi pada suhu (A) $500{ }^{\circ} \mathrm{C}$, (B) 600 ${ }^{\circ} \mathrm{C}$, (C) $800{ }^{\circ} \mathrm{C}$ dan (D) $1000{ }^{\circ} \mathrm{C}$.

Gambar SEM juga menunjukkan arah pentumbuhannya, sebagian besar kristal berbentuk panjang kedepan tumbuh kearah a dan c. Hal ini sesuai dengan hasil XRD bidang pertumbuhan (200) dan (-201) pada sudut $2 \theta=11,8^{\circ}$ dan $14,1^{\circ}$ dengan intensitas yang lebih tinggi.

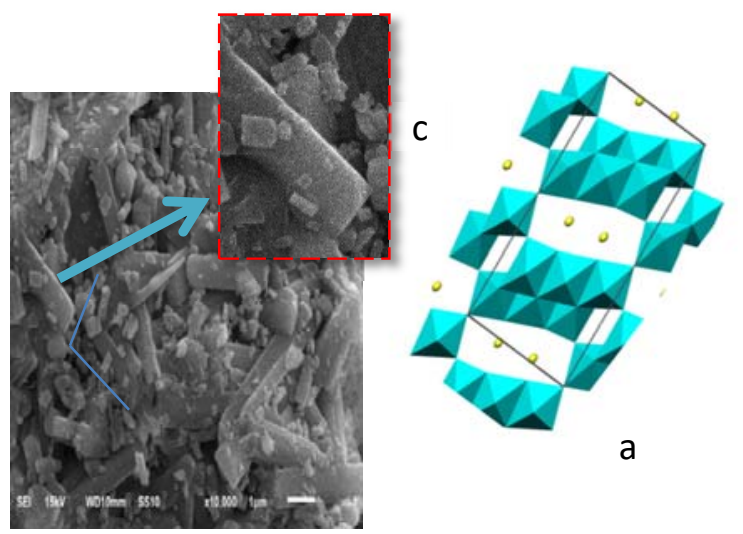

Gambar 8. Representasi pertumbuhan kristal $\mathrm{Na}_{2} \mathrm{Ti}_{6} \mathrm{O}_{13}$ pada bidang (200) dan (-201).

\subsection{Analisis UV-Vis}

Nilai lebar celah pita energi dari serbuk $\mathrm{Na}_{2} \mathrm{Ti}_{6} \mathrm{O}_{13}$ diperoleh dengan melakukan pengukuran DRS. Spektrum yang diperoleh diubah menjadi spektrum absorpsi dengan metode Kubelka-Munk. Lebar celah pita energi diperoleh dari hasil plot $(\alpha h v)^{\wedge} 2$ dengan energi $(\mathrm{eV})$. Di mana $\alpha$ adalah koofisien absorpsi dan hv merupakan energi foton. Dari kurva yang diperoleh, kemudian ditarik garis lurus sampai ke sumbu-x. Nilai yang diperoleh merupakan perkiraan lebar celah pita energi dari sampel. Pada gambar 9 memperlihatkan perbandingan nilai lebar celah pita energi dari semua sampel. 

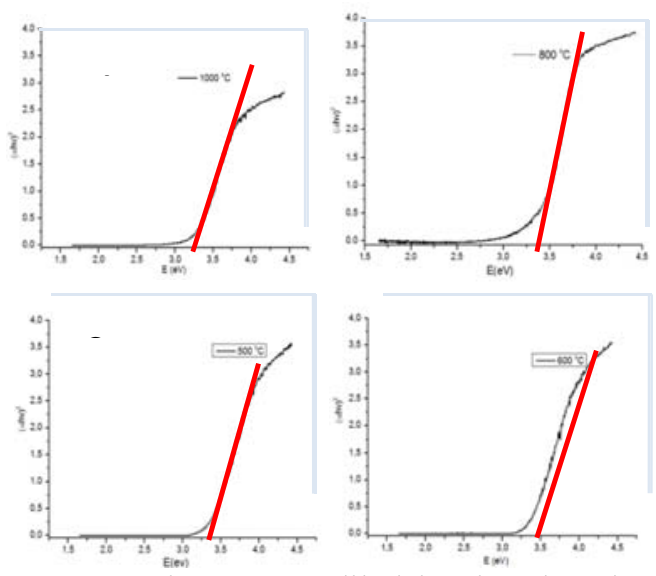

Gambar 9. Spektum DRS $\mathrm{Na}_{2} \mathrm{Ti}_{6} \mathrm{O}_{13}$ yang dikalsinasi pada suhu (A) $1000{ }^{\circ} \mathrm{C}$, (B) 800 ${ }^{\circ} \mathrm{C}$, (C) $500{ }^{\circ} \mathrm{C}$ dan (D) $600{ }^{\circ} \mathrm{C}$.

Nilai lebar celah pita energi sampel yang dikalsinasi pada masing-masing pada suhu $500{ }^{\circ} \mathrm{C}, 600{ }^{\circ} \mathrm{C}, 800{ }^{\circ} \mathrm{C}$, dan $1000^{\circ} \mathrm{C}$ adalah $3,30 \mathrm{eV}, 3,29 \mathrm{eV}, 3,40 \mathrm{eV}$, dan $3,25 \mathrm{eV}$. Semua sampel memiliki nilai celah pita energi yang lebar berkisar di daerah UV. Hal ini berarti bahwa katalis hanya aktif apabila diberi energi cahaya sama dengan energi UV. Oleh karena itu, perlu dilakukan modifikasi terhadap sturktur $\mathrm{Na}_{2} \mathrm{Ti}_{6} \mathrm{O}_{13}$ untuk mempersempit nilai celah pita energi tersebut.

\section{KESIMPULAN}

Natrium heksa titanat $\left(\mathrm{Na}_{2} \mathrm{Ti}_{6} \mathrm{O}_{13}\right)$ telah berhasil disintesis menggunakan metode hidrotermal pada suhu $150{ }^{\circ} \mathrm{C}$ selama 24 jam. $\mathrm{Na}_{2} \mathrm{Ti}_{6} \mathrm{O}_{13}$ mempunyai ukuran $48,4 \mathrm{~nm}$, lebar celah pita energi $\left(\mathrm{E}_{\mathrm{g}}\right) 3,40 \mathrm{eV}$. $\mathrm{Na}_{2} \mathrm{Ti}_{6} \mathrm{O}_{13}$ mempunyai sistem kristal monoklinik dengan parameter $\mathrm{a}=15,21 \AA, \mathrm{b}=3,744 \AA, \mathrm{c}=9,165 \AA$, dan $\beta=99,05^{\circ}$.

\section{DAFTAR PUSTAKA}

[1] Xing J., Fang W Q., Zhao H J., \& Yang H G. (2012). Inorganic Photocatalysts for Overall Water Splitting. Chemistry An Asian Journal, 7, 642 - 657.

[2] Vithal M., Rama K.S., Ravi S. G., Velchuri R., \& Pola S. (2013). Synthesis of $\mathrm{Cu}^{2+}$ and $\mathrm{Ag}^{+}$doped $\mathrm{Na}_{2} \mathrm{Ti}_{3} \mathrm{O}_{7}$ by afacileion-exchange method asvisible-light-driven photocatalysts. Ceramics International, 39, 8429-8439.

[3] Verdulthi N K., Ravi G., Reddy J R., Palla S., Muniratnam N R., Prasad G., \& Vithal M. (2014). Facile ion-exchange synthesis and visible light photocatalyst studies of $\mathrm{Cu}^{2+}, \mathrm{Sn}^{2+}$ and $\mathrm{Ag}^{+}$subtituted $\mathrm{LiMg}_{0,5} \mathrm{Ti}_{0,5} \mathrm{O}_{2}$. Journal American Ceramis Society, 97(6), 1829-1836.

[4] Arsana P., Bubpa C., \& Sang-aron W. (2012). Photocatalytic activity under irradition of silver and copper doped zincoxide: photodepisition versun liquid impregnation metode. Journal of Applied Sciences, 12(17), 1809-1816. 
[5] Vaiano V., Sacco O., Sannino D., \& Ciambelli P. (2015). Process intensification in the removal of organic pollutants from wastewater u. C., Martíneza L.M.T., Zanellad R., Sandovala F.J. A., \& Sánchez .K. Del Á.(2013). Improving water sing innovative photocatalysts obtained coupling zinc sulfide based phosphors with nitrogen doped semiconductors. Journal of Cleaner Production, 100, 208-211.

[6] Cuchilloa O V., Gómezc R., Lópeza. A. (2013). Improving water splitting using $\mathrm{RuO}_{2}-\mathrm{Zr} / \mathrm{Na}_{2} \mathrm{Ti}_{6} \mathrm{O}_{13}$ as a photocatalyst. Journal of Photochemistry and Photobiology A: Chemistry, 266, 6- 11.

[7] Vossoughi M., Ghanbari F., Simchi A., \& Shidpour R. (2014). Photo-degradation of organic dye by zinc oxide nanosystems with special defect structure: Effect of the morphology and annealing temperature. Applied Catalysis A: General, 472, 198-204.

[8] Sood a, Swati., Umar Ahmad., Meht S K., \& Kansal S K. (2015). Highly effective Fe-doped $\mathrm{TiO}_{2}$ nanoparticles photocatalysts for visiblelight driven photocatalytic degradation of toxic organic compounds. Journal of Colloid and Interface Science, $450,213-223$.

[9] Zuo R., Du G., Zhang W., Liu L., Liu Y., Mei L., \& Li Z. (2014). Photocatalytic Degradation of Methylene Blue Using TiO2 Impregnated Diatomite. Advances in Materials Science and Engineering, 201, 7.

[10] Smith A M., \& Nie S. (2010). Semiconductor Nanocrystals: Structure, Properties, and Band Gap Engineering. Accaunts of chemical research, 43, 190-200.

[11] Pérez-Flores J.C., Kuhn A., \& García-Alvarado F. (2011). Synthesis, structure and electrochemical li insertion behaviour of $\mathrm{ii}_{2} \mathrm{Ti}_{6} \mathrm{O}_{13}$ with the $\mathrm{Na}_{2} \mathrm{Ti}_{6} \mathrm{O}_{13}$ tunnelstructure. Journal of Power Sources, 196 (3), 1378-1385.

[12] Zhen L., Xu C.Y., Wang W.S., Lao C.S., \& Kuang Q. (2009). Electrical and photocatalytic properties of $\mathrm{Na}_{2} \mathrm{Ti}_{6} \mathrm{O}_{13}$ nanobelts prepared by molten salt synthesis. Applied Surface Science, 255(7), 4149-4152.

[13] Viana B C., Ferreira O P., Filho A G S., Filho J M., and Alves O L. (2009). Structural, Morphological and Vibrational Properties of Titanate Nanotubes and Nanoribbons. Journal Brazil Chemical Society, 20 (1), 167-175.

[14] Liu S., Yu J., \& Jaroniec M. (2010). Tunable photocatalytic selectivity of hollow $\mathrm{TiO}_{2}$ microspheres composed of anatase polyhedra with exposed $\{001\}$ facets. Journal of the American Chemical Society, 34, 132.

[15] Norris D J., Efros A L., \& Erwin S C. (2008). Doped Nanocrystals . Science, 319.

[16] Erwin S C., Zu Lijun., Haftel M., Efros AL., Kennedy T A., \& Norris D J. Doping semiconductor nanocrystals. Nature, 436. 
[17] Amri I., \& Nurlaela E. (2011). Study Hybrid Desain Membrane Fotokatalitic Reaktor Untuk Menghasilkan Hidrogen dari Air. Proseding SNTK TOPI Pekanbaru, 1907.

[18] Bonanni A. (2007). Ferromagnetic nitride-based semiconductors doped with transition metals and rare earths. Semiconductor Science and Technology, 22, 4156.

[19] Yahya R., Hayashi H., Nagase T., Ebina T., Onodera Y., \& Saitoh N. (2001) Hydrothermal Synthesis of Potassium Hexatitanates under Subcritical and Supercritical Water Conditions and Its Application in Photocatalysis. Journal of the American Chemical Society, 13, 3.

[20] Suchanek W L., \& Riman R E. (2006). Hydrothermal Synthesis of Advanced Ceramic Powders. Advances in Science and Technology, 45, 184-193.

[21] Zarrate R A., Fuentes S., Cabrera A L., \& Fuenzalida V M. (2008). Structural characterization of single crystals of sodium titanate nanowires prepared by hydrothermal process. Journal of Crystal Growth, 310, 3630- 3637.

[22] Liu H., Yang D., Zheng Z., Ke X., Waclaik E., Zhu H., \& Frost R 1. (2010). A Raman spectroscopic and TEM study on the structural evolution of $\mathrm{Na}_{2} \mathrm{Ti}_{3} \mathrm{O}_{7}$ during the transition to $\mathrm{Na}_{2} \mathrm{Ti}_{6} \mathrm{O}_{13}$. J. Raman Spectroscopy, 41, 1331-1337.

[23] Flores J C P., Alvarado F G., Hoelzel M., Sobrados I., Sanzc J \& Kuhn A. (2012). Insight into the channel ion distribution and influence on the lithium insertion properties hexatitanates $\mathrm{A}_{2} \mathrm{Ti}_{6} \mathrm{O}_{13}(\mathrm{~A}=\mathrm{Na}, \mathrm{Li}, \mathrm{H})$ as candidates for anode materials in lithium-ion batteries. Paper of Dalton Transactions, 41, 14633-14642. 